Ind. Health, 1975, 13, 51.

\title{
EFFECT OF ZINC ON MANGANESE INDUCED TESTICULAR INJURY IN RATS
}

\author{
Satya V. Chandra, Daya K. Saxena and Mohammed Z. Hasan
}

Industrial Toxicology Research Centre, Lucknow, U.P., India

(Received April 18, 1975)

\begin{abstract}
The effect of zinc on manganese induced testicular injury was investigated. It was observed that daily intraperitoneal administration of $\mathrm{MnSO}_{4} \cdot 4 \mathrm{H}_{2} \mathrm{O}(6 \mathrm{mg} \mathrm{Mn} / \mathrm{kg})$ to the rats for 30 days produced degeneration of some of the seminiferous tubules whereas simultaneous administratiou of $\mathrm{ZnSO}_{4} \cdot 7 \mathrm{H}_{2} \mathrm{O}(2 \mathrm{mg} / \mathrm{kg})$ to these rats protected them from the toxic effects of manganese on testis. The concentration of manganese in testis of rats treated with manganese and zinc salts was lower as compared to that observed in testis of rats treated with manganese alone, while zinc content in this group was significantly higher than in the testis of animals treated with zinc alone. The exact mechanism of interaction of these two metals in protecting testis from injurious effects of manganese is not known.
\end{abstract}

Manganese produces profound damage to the testicular tissue of experimental animals ${ }^{1 \sim 3}$ ) leading to infertility in male rabbits. ${ }^{4)}$ Recently the interest in the occurrence of zinc in the testis as an essential mineral for the complete development and maturation of spermatozoa has been renewed particularly due to its role in prevention of cadmium induced testicular injury. ${ }^{5 \sim 7}$ Large doses of zinc salts administered simultaneously with cadmium produces complete morphological protection in the rats. ${ }^{8)}$ It was, therefore, of interest to investigate the effect of zinc salts on the manganese induced testicular toxicity in experimental animals. Estimation of manganese and zinc contents of testicular tissue were also done in order to understand the mechanism of interaction of the two metals in this organ.

\section{Materials And Methods}

Industrial Toxicology Research Centre bred adult male hooded rats weighing $150 \pm$ $20 \mathrm{~g}$ were used in this study. They were housed in an air conditioned room, fed pellet diet from Hindustan Levers India Ltd., and tap water ad libitum. The animals were divided randomly into four groups. Group I comprising of 10 animals received daily by intraperitoneal injection $0.2 \mathrm{ml}$ of physiological saline for 30 days and served as controls. Ten rats of group II were administered daily by the same route $\mathrm{MnSO}_{4} \cdot 4 \mathrm{H}_{2} \mathrm{O}(6 \mathrm{mg} \mathrm{Mn} / \mathrm{kg}$, purchased from B.D.H., A.R. grade) dissolved in $0.2 \mathrm{~m} l$ physiological saline for the same period. Another 10 rats (Group III) were injected daily by intraperitoneal route 


\section{S.V. CHANDRA, D.K. SAXENA AND M.Z. HASAN}

$\mathrm{ZnSO}_{4} \cdot 7 \mathrm{H}_{2} \mathrm{O}(2 \mathrm{mg} / \mathrm{kg}$, purchased from B.D.H., A.R. grade) dissolved in $0.2 \mathrm{ml}$ physiological saline for 30 days. Group IV consisting of another 10 rats were injected daily intraperitoneally $\mathrm{ZnSO}_{4} \cdot 7 \mathrm{H}_{2} \mathrm{O}(2 \mathrm{mg} / \mathrm{kg}$ ) dissolved in $0.2 \mathrm{ml}$ of physiological saline in the morning and in the afternoon were administered by the same route with $\mathrm{MnSO}_{4} \cdot 4 \mathrm{H}_{2} \mathrm{O}$ $(6 \mathrm{mg} \mathrm{Mn} / \mathrm{kg}$ ) dissolved in $0.2 \mathrm{ml}$ of physiological saline for 30 days.

All the animals were sacrificed at the end of the experimental period with ether anaesthesia, one testis was kept for the estimation of manganese and zinc contents and the other testis from each rat was fixed in $10 \%$ neutral formalin for histology. After routine processing the tissues were embedded in paraffin and sections were cut at $5 \mu$. The staining was done with haematoxylin and eosin and for the histochemical demonstration of calcium by the method of Von Kossa. ${ }^{9}$

\section{Estimations of manganese and zinc}

All the precautions in handling the tissues for manganese and zinc estimations were taken as described by Christian et al. ${ }^{10}$ ) The individual testis was weighed and dried at $110^{\circ} \mathrm{C}$ for $5 \mathrm{hr}$ in a platinum crucible and then ashed in a muffle furnace at $600^{\circ} \mathrm{C}$ for a further period of $4 \mathrm{hr}$. The ash was treated twice with $2 \mathrm{ml}$ of concentrated nitric acid and evaporated to dryness. The residual ash was dissolved in $5 \mathrm{ml}$ of $0.1 \mathrm{~N} \mathrm{HCl}$. The readings for manganese and zinc were taken in Perkin-Elmer model-303 double beam atomic absorption spectrophotometer equipped with Boling burner and null read out accessory. The instrument was set up for maximum sensitivity. Hollow cathode lamps for manganese and zinc were used separately. Acetylene air mixture was used as fuel. The readings for manganese and zinc were taken at the wavelength of $2795 \AA$ and $2139 \AA$ respectively.

The test described by Fisher ${ }^{11}$ ) was employed to analyze the data. The statistical significance was calculated between two values of control and treated rats and a value of 0.05 or less was considered significant.

\section{RESULTS}

None of the animals died during the course of the experiments. On autopsy the testes did not reveal any gross change in all the groups.

\section{Histopathological observations}

The histological pattern of testis of a normal animal showed an orderly arrangement of germ cells in the seminiferous tubules and normal interstitial tissue with Leydig cells and blood vessels (Fig. 1). The sections of testis after $\mathrm{MnSO}_{4} \cdot 4 \mathrm{H}_{2} \mathrm{O}(6 \mathrm{mg} \mathrm{Mn} / \mathrm{kg}$ ) administration for 30 days showed degenerative changes in the seminiferous epithelium of some of the tubules, the number of spermatids were markedly depleted and these tubules were devoid 


\section{EFFECT OF ZINC ON MANGANESE INDUCED INJURY}

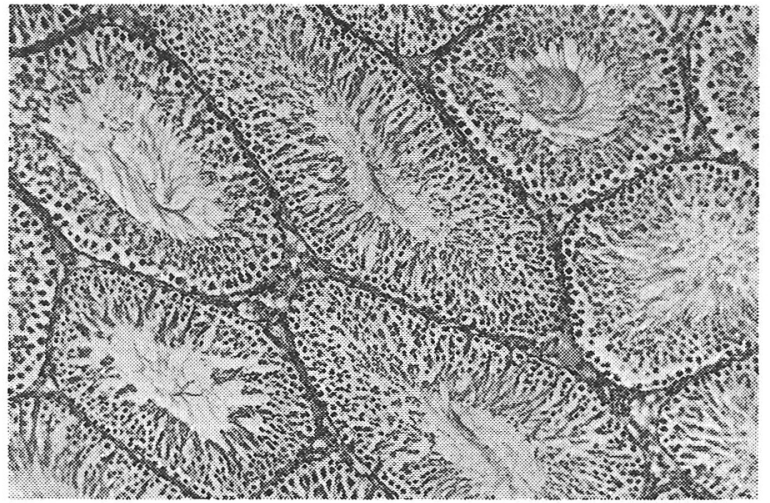

Fig. 1. Section of testis of normal rat showing orderly arrangement of germ cells in the seminifeous tubules and interstitial tissue. H \& EX 195.

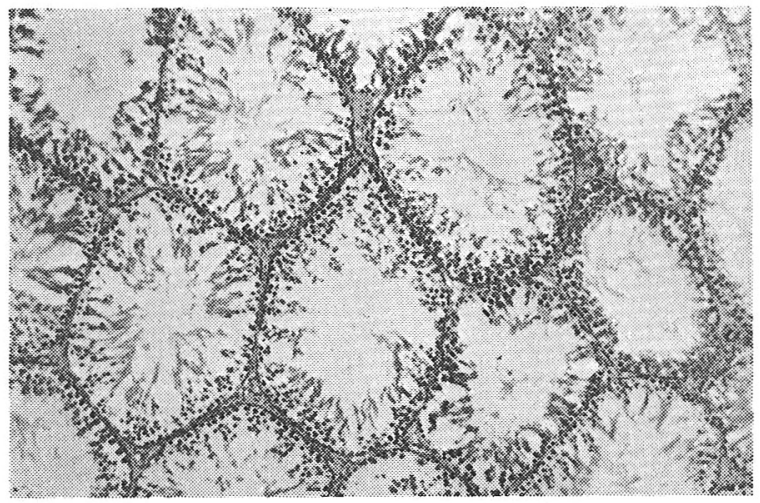

Fig. 2. Section of testis of a rat treated with $\mathrm{MnSO}_{4} \cdot 4 \mathrm{H}_{2} \mathrm{O}$ ( $6 \mathrm{mg} \mathrm{Mn} / \mathrm{kg}$ ) for 30 days, showing degenerative changes in the seminiferous epithelium. These tubules are devoid of spermatocytes.

H \& EX 195.

of spermatocytes (Fig. 2). The interstitial tissue did not show any change. The sections of testis of a rat treated with $\mathrm{ZnSO}_{4} \cdot 7 \mathrm{H}_{2} \mathrm{O}(2 \mathrm{mg} / \mathrm{kg})$ for 30 days did not show any morphological change, only slight oedema was observed in the interstitial tissue (Fig. 3).

The testis of rat treated with both the metal salts (Group IV) did not reveal any pathological change (Fig. 4).

\section{Manganese and zinc contents in testes}

Manganese and zinc contents of testis in all the four groups are shown in Table 1. The contents of manganese in groups II $\left(\mathrm{MnSO}_{4} \cdot 4 \mathrm{H}_{2} \mathrm{O}, 6 \mathrm{mg} \mathrm{Mn} / \mathrm{kg}\right)$ and in IV $\left(\mathrm{MnSO}_{4}\right.$. $4 \mathrm{H}_{2} \mathrm{O}, 6 \mathrm{mg} \mathrm{Mn} / \mathrm{kg}+\mathrm{ZnSO}_{4} \cdot 7 \mathrm{H}_{2} \mathrm{O}, 2 \mathrm{mg} / \mathrm{kg}$ ) were $0.723 \pm 0.01$ and $0.573 \pm 0.01 \mu \mathrm{g} / \mathrm{g}$ fresh 


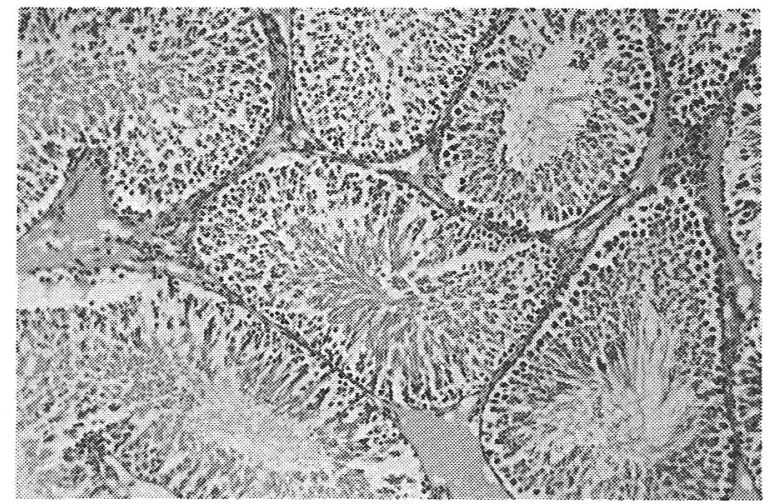

Fig. 3. Section of testis of a rat treated with $\mathrm{ZnSO}_{4} \cdot 7 \mathrm{H}_{2} \mathrm{O}$ ( $2 \mathrm{mg} / \mathrm{kg}$ ) for 30 days, showing normal tubules and slight oedema of interstitial tissue.

H \& EX 195.

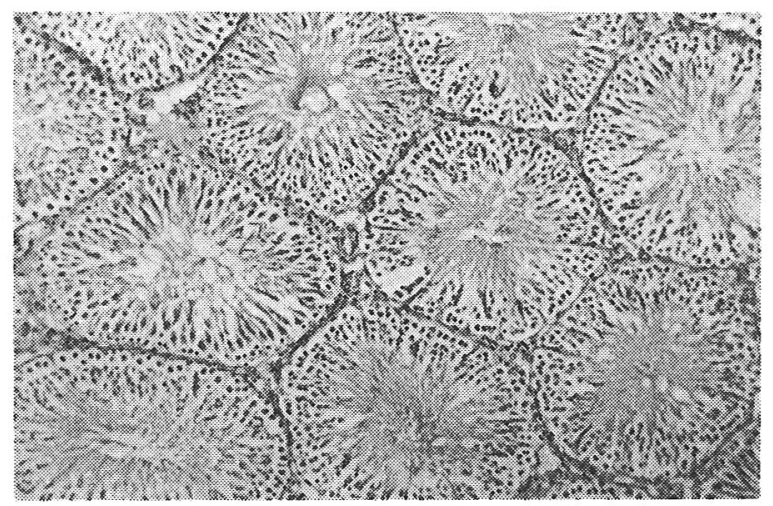

Fig. 4. Section of testis of a rat treated with $\mathrm{MnSO}_{4} \cdot 4 \mathrm{H}_{2} \mathrm{O}$ ( $6 \mathrm{mg} \mathrm{Mn} / \mathrm{kg}$ ) and $\mathrm{ZnSO}_{4} \cdot 7 \mathrm{H}_{2} \mathrm{O}(2 \mathrm{mg} / \mathrm{kg}$ ) for 30 days showing normal pattern of testicular tissue.

H \& EX 195.

Table 1. Manganess and zinc contents in testis.

\begin{tabular}{|c|c|c|c|}
\hline $\begin{array}{l}\text { Groups } \\
\text { (No. of Rats) }\end{array}$ & $\begin{array}{l}\text { Treatment given daily } \\
\quad \text { for } 30 \text { days }\end{array}$ & $\begin{array}{l}\text { Manganese contents } \\
\mu \mathrm{g} / \mathrm{g} \text { of wet tissue }\end{array}$ & $\begin{array}{c}\text { Zinc contents } \\
\mu \mathrm{g} / \mathrm{g} \text { of wet tissue }\end{array}$ \\
\hline I $(10)$ & $\begin{array}{l}0.2 \mathrm{~m} l \text { physiological saline } \\
\text { intraperitoneally (controls) }\end{array}$ & $0.302 \pm 0.06$ & $6.753 \pm 0.72$ \\
\hline II $(10)$ & $\begin{array}{l}\mathrm{MnSO}_{4} \cdot 4 \mathrm{H}_{2} \mathrm{O}, 6 \mathrm{mg} \mathrm{Mn} / \mathrm{kg} \\
\text { intraperitoneally }\end{array}$ & $\begin{array}{l}0.723 \pm 0.01 \\
\mathrm{p}<.01\end{array}$ & $\begin{array}{l}8.111 \pm 0.6 \\
\mathrm{p}<.05\end{array}$ \\
\hline III $(10)$ & $\begin{array}{l}\mathrm{ZnSO}_{4} \cdot 7 \mathrm{H}_{2} \mathrm{O}, 2 \mathrm{mg} / \mathrm{kg} \\
\text { intraperitoneally }\end{array}$ & $\begin{array}{l}0.429 \pm 0.01 \\
\text { N.S. }\end{array}$ & $\begin{array}{l}9.80 \pm 0.5 \\
\mathrm{p}<.01\end{array}$ \\
\hline IV (10) & $\begin{array}{l}\mathrm{MnSO}_{4} \cdot 4 \mathrm{H}_{2} \mathrm{O}, 6 \mathrm{mg} \mathrm{Mn} / \mathrm{kg} \\
\text { and } \mathrm{ZnSO}_{4} \cdot 7 \mathrm{H}_{2} \mathrm{O}, 2 \mathrm{mg} / \mathrm{kg} \\
\text { intraperitoneally }\end{array}$ & $\begin{array}{l}0.573 \pm 0.01 \\
\mathrm{p}<.01\end{array}$ & $\begin{array}{l}11.09 \pm 0.32 \\
\mathrm{p}<.001\end{array}$ \\
\hline
\end{tabular}

Values represent the mean \pm S.E. of 6 rats p values of 0.05 or less are significant. 


\section{EFFECT OF ZINC ON MANGANESE INDUCED INJURY}

tissue respectively which were significantly higher than the manganese concentration in normal controls $(0.302 \pm 0.06 \mu \mathrm{g} / \mathrm{g}$ fresh tissue). The contents of manganese in testis of manganese treated rats was higher than in animals treated with both the metals. The contents of zinc in testis of rats of group III $\left(\mathrm{ZnSO}_{4} \cdot 7 \mathrm{H}_{2} \mathrm{O}, 2 \mathrm{mg} / \mathrm{kg}\right)$ were $9.80 \pm 0.5 \mu \mathrm{g} / \mathrm{g}$ fresh tissue which was significantly higher $(\mathrm{P}<.01)$ than the values in normal controls $(6.753 \pm 0.72 \mu \mathrm{g} / \mathrm{g}$ fresh tissue). The zinc contents in testis of rats treated simultaneously with manganese and zinc sulphates were $11.09 \pm 0.32 \mu \mathrm{g} / \mathrm{g}$ fresh tissue. The increase in the zinc contents in this group was highly significant $(\mathrm{P}<.001)$ than in normal controls.

\section{Discussion}

Interaction of certain metals in enhancing or minimizing the toxicity of each other is well known although the mechanism of such effects remains to be established. Chronic and acute toxicity of selenium is reduced by the administration of arsenic. ${ }^{12}$ Supplementation with selenium protects against mercury intoxication. ${ }^{13)}$ Iron or chromium deficiency enhances lead toxicity, ${ }^{14)}$ iron deficiency also increase mangancse toxicity. ${ }^{15}$ ) In the present experiments zinc appears to be beneficial in preventing the toxic effects of manganese on testicular tissue. Administration of manganese alone produces degenerative changes in seminiferous tubules of rats but these morphological alterations are not observed when small doses of zinc are administered simultaneously to the rats. Zinc also protects the animal from the toxic effects of cadmium on testis but the mechanism of protection may not be similar in both the cases. Unlike cadmium, manganese in early stages of toxicity does not seem to effect the interstitium or testicular vasculature.

Our investigations have clearly shown that the increase in manganese content in testis of rats treated with both manganese and zinc sulphates is less than in testicular tissue of animals administered with manganese sulphate alone. On the other hand the increase in the testicular contents of zinc is more in animals treated with both the salts as compared to the zinc contents of testis after treatment with zinc sulphate alone. In other words simultaneous administration of manganese and zinc in experimental animals results in less accumulation of manganese and more concentration of zinc in testis. Excess of zinc may be preventing the interference of manganese with the energy synthesizing enzyme system of the cells of seminiferous tubules and thus preventing the cellular death; however, understanding of the exact mechanism needs further work.

\section{ACKNOWLEDGEMENTS}

The authors are grateful to Dr. S. H. Zaidi for his interest in this study. The technical assistance of Mr. R. S. Srivastava, G. Husain and I. Ansari and microphotography of Mr. M. Ahmed is gratefully acknowledged. 


\section{S.V. CHANDRA, D.K. SAXENA AND M.Z. HASAN}

\section{REFERENCES}

1) Chandra, S.V. (1971). Acta Pharmacol. Toxicol., 29, 75.

2) Singh, J., Husain, R., Tandon, S.K., Seth, P.K. and Chandra, S.V. (1974). Environ. Physiol. Biochem., 4, 16.

3) Imam, Z. and Chandra, S.V. (1975). Toxicol. Appl. Pharmacol. (In press).

4) Chandra, S.V., Ara, R., Nagar, N. and Seth, P.K. (1973). Acta Biol. Med. Germ., 6, 30.

5) Elcoate, P.V., Fischer, M.I., Mawson, C.A. and Miller, N.J. (1955). J. Physiol., 129, 53.

6) Johnson, A.D., Gomes, W.R. and Vandemark, N.L. (1970). The Testis. Academic Press, New York and London.

7) Gunn, A.S., Gould, T.C., Anderson, W.A. and Gables, C. (1961). Arch. Pathol., 71, 274.

8) Parizek, J. (1957). J. Endocrinol., 15, 56.

9) McManus, J.F.A. and Mowry, R.W. (1965). Staining Methods; Histologic and Histochemical. Hoeber Medical Division Harper \& Row, New York.

10) Christian, G.D. and Feldman, F.J. (1970). Atomic Absorption Spectroscopy. WileyInterscience, New York.

11) Fisher, R.A. (1950). Statistical Methods for Research Workers, 11th ed. Oliver \& Boyd, London.

12) Levander, O.A. and Bawmann, A. (1966). Toxicol. Appl. Pharmacol., 9, 98.

13) Ganther, H.E. and Bawmann, C.A. (1962). J. Nutr., 77, 210.

14) Six, K.M. and Goyer, R.A. (1972). J. Lab. Clin. Med., 79, 128.

15) Chandra, S.V. and Tandon, S.K. (1973). Environ. Physiol. Biochem., 3, 230. 